\title{
Pengembangan Bahan Ajar Matematika Berbentuk Leaflet Berbasis Kemampuan Kognitif Siswa Berdasarkan Teori Bruner
}

\author{
Widodo Winarso ${ }^{1}$, Dede Dewi Yuliyanti ${ }^{2}$ \\ ${ }^{1,2}$ Jurusan Tadris Matematika, Fakultas Ilmu Tarbiyah dan Keguruan, IAIN Syekh Nurjati Cirebon \\ E-mail : widodoiain@gmail.com,dede2a1smanji@gmail.com
}

\begin{abstract}
Abstrak
Banyak siswa yang kurang tertarik dengan matematika. Oleh karena itu, inovasi menjadi penting agar pembelajaran matematika dapat dikemas secara menarik. Salah satu inovasi adalah pengembangan bahan ajar untuk menciptakan bahan ajar dalam bentuk selebaran. Tujuan dari penelitian ini adalah untuk mengembangkan materi pengajaran leaflet pada mata pelajaran kubus dan balok berdasarkan kemampuan kognitif siswa berdasarkan teori Bruner. Tahap kognitif Bruner menunjukkan bahwa ada tiga tahap enaktif, ikonik dan simbolis. Metode penelitian yang digunakan peneliti adalah metode penelitian dan pengembangan. Model yang digunakan adalah pengembangan desain menurut Sugiyono, terdiri dari identifikasi masalah, pengumpulan data, persiapan bahan ajar, validasi desain, revisi desain, pengujian produk, revisi produk, pengujian utilitas. Aspek penilaian yang digunakan adalah penilaian produk oleh para ahli, tes kemampuan kognitif siswa berdasarkan teori Bruner dan lembar tanggapan siswa. Dalam penilaian produk terdiri dari konten layak, tampilan, bahasa, dan kelengkapan komponen.
\end{abstract}

Kata Kunci: Leaflet; Teori Bruner; Matematika

\begin{abstract}
Many students who are less interested in math. Therefore, innovation becomes important so that math learning can be attractively packaged. One of innovation is a development of teaching materials to create teaching materials in the form of the leaflet. The purpose of this study is to develop leaflet teaching materials on the subjects of cube and beam based on student's cognitive abilities referred Bruner's theory. Bruner's cognitive stage of the theory that there are three stages enaktif, iconic and symbolic. A research method that used by researcher is research method and development. The model used is the design development according to Sugiyono, consists of problem identification, data collection, preparation of teaching materials, design validation, design revisions, product testing, product revision, utility testing. Aspects of assessment used were the product assessment by experts, cognitive ability tests students based on the theory of Bruner and student response sheet. In the product assessment consist of worthiness content, display, language, and completeness of the component
\end{abstract}

Keywords: Leaflet; Bruner Theory; Math 


\section{PENDAHULUAN}

Matematika sebagai ilmu universal mendasari perkembangan teknologi modern, mempunyai peran penting dalam berbagai disiplin ilmu. Matematika digunakan di seluruh dunia sebagai alat penting di beberapa bidang, termasuk ilmu alam, kedokteran dan ilmu sosial seperti ekonomi dan psikologi. Mata pelajaran matematika diajarkan mulai dari jenjang Pendidikan Anak Usia Dini (PAUD) sampai dengan Sekolah Menengah Atas (SMA). Hal ini dikarenakan matematika merupakan ilmu pengetahuan yang penting sebagai pengantar dan dasar dari ilmu pengetahuan lain (Gallenstein, 2003; Suriasumantri, 1999).

Memang sampai sekarang, matematika sering dianggap sebagai salah satu pelajaran yang paling sulit bagi siswa (Stodolsky, Salk \& Glaessner, 1991). Efek negatif dari pandangan ini yakni ada beberapa siswa yang sudah anti dengan matematika sebelum mereka benar-benar belajar matematika. Pada akhirnya terbentuklah lingkaran setan bahwa matematika itu sulit karena siswa malas untuk belajar matematika. Siswa malas belajar matematika bisa disebabkan oleh banyak faktor di antaranya siswa tidak tertarik dengan matematika. Oleh karena itu pentingnya inovasi dalam pembelajaran matematika supaya pembelajaran matematika dapat dikemas dengan menarik.

Sebagai contoh di Finlandia, guruguru di Finlandia dibebaskan menyusun kurikulum dan silabus sesuai dengan visi dan misi sekolah. Dengan kreatif, mereka merancang buku teks yang aplikatif. Hampir semua guru menjadi penulis, minimal penulis buku pelajaran yang mereka gunakan di kelas. Dampak dari otonomi guru tersebut menjadikan guru-guru Finlandia sangat bertanggung jawab terhadap keberhasilan pen- didikan para siswanya. Maka hasilnya dari pembuatan bahan ajar tersebut Finlandia mampu menjaga posisinya pada 10 besar menurut survei PISA (Putra, 2015; Baswedan, 2014; Chatib, 2012; Fajar, 1993).

Sebaiknya pembelajaran matematika itu dapat mengaitkan antara materi yang diajarkan dengan situasi nyata siswa dan mendorong siswa membuat hubungan yang berkaitan dengan kegiatan sehari-hari yang siswa lakukan (Krismanto, 2003; Calinger, Brown \& West, 1999). Agar siswa dapat mengikuti pelajaran dengan maksimal, maka mereka perlu memiliki buku untuk sumber belajar, karena ketersediaan buku sumber yang kurang memadai maka guru harus mengatasi hal ini dengan membuat bahan ajar (Otieno, 2010; Yunanto, 2004). Oleh karena itu guru perlu mengembangkan kreativitas sendiri agar mampu membuat bahan ajar yang inovatif untuk menunjang kemampuan kognitif siswa.

Teori belajar Bruner cocok jika diterapkan dalam pembelajaran matematika, perkembangan kognitif siswa berdasarkan teori belajar Bruner berawal dari tahap enaktif yaitu tahap dimana siswa belajar berawal dari benda-benda yang konkret yang berhubungan dengan dunia nyata, kemudian tahap ikonik pada tahap ini pengetahuan dipresentasekan dalam bentuk bayangan visual atau gambar yang meng-gambarkan kegiatan konkret pada tahap enaktif, dan terakhir yaitu tahap simbolik dimana siswa diajak untuk merepresentasi-kan gambar menjadi simbol-simbol matematika (Bruner, 1966; Olson, 2014; Lestari, 2014).

Menururt Septiani, Jalmo, \& Yolida (2014) bahwa bahan ajar yang lebih menarik dari buku paket adalah bahan ajar leaflet. Hal tersebut di karenakan bahan ajar leaflet sangatlah sederhana dan dilihat dari penam- 
pilannya siswa lebih tertarik dalam belajar. Sejalan dengan hal tersebut Purnomo (2012) memandang Leaflet memberikan pemahaman bagi siswa bahwa matematika itu tidak serumit buku teks yang tebal, tapi matematika itu bisa dikemas menjadi suatu hal yang menarik dan indah.

Dari pemaparan tersebut, sehingga tertarik untuk mengkaji tentang Pengembangan bahan ajar kubus dan balok berbentuk leaaflet berbasis kemampuan kognitif siswa berdasarkan teori Bruner.

\section{METODE}

Populasi adalah himpunan yang lengkap dari satuan-satuan atau individuindividu yang karakteristiknya ingin kita ketahui. Menurut Arikunto (2010) mendefinisikan populasi adalah keseluruhan subjek penelitian. Populasi dalam penelitian ini adalah seluruh peserta didik kelas VIII SMPN 4 Palimanan pada tahun ajaran 20152016 yang berjumlah 242 peserta didik yang dari 7 rombongan belajar (rombel).

Teknik pengambilan sampel yang digunakan adalah judgement sampling (dikenal dengan purposive sampling) adalah teknik penarikan sampel yang dilakukan berdasarkan karakteristik yang ditetapkan terhadap elemen populasi target yang disesuaikan dengan tujuan atau masalah penelitian (Kothari, 2004).

Teknik pengambilan sampel pada penelitian ini peneliti memilih sendiri kelas yang akan menjadi sampel penelitian. Kelas yang digunakan untuk penelitian adalah kelas VIII D. Alasan ditetapkannya kelas VIII D karena selama PPL 2 peneliti mengajar di kelas VIII D, peneliti sudah mengenal karakteristik siswa dan sudah melakukan analisis kebutuhan siswa di kelas VIII D selama 3 bulan mengajar dan alasan lainnya karena kelas VIII D memiliki nilai rata-rata ulangan harian yang kecil di antara kelas lainnya

Metode penelitian yang digunakan adalah metode penelitian dan pengembangan atau dalam bahasa inggrisnya Research and Development adalah metode penelitian yang digunakan untuk menghasilkan produk tertentu, dan menguji keefektifan produk tersebut (Van den Akker, 1999). Desain penelitian yang digunakan oleh peneliti adalah desain pengembangan Sugiyono. (2008) dengan alur sebagai berikut.

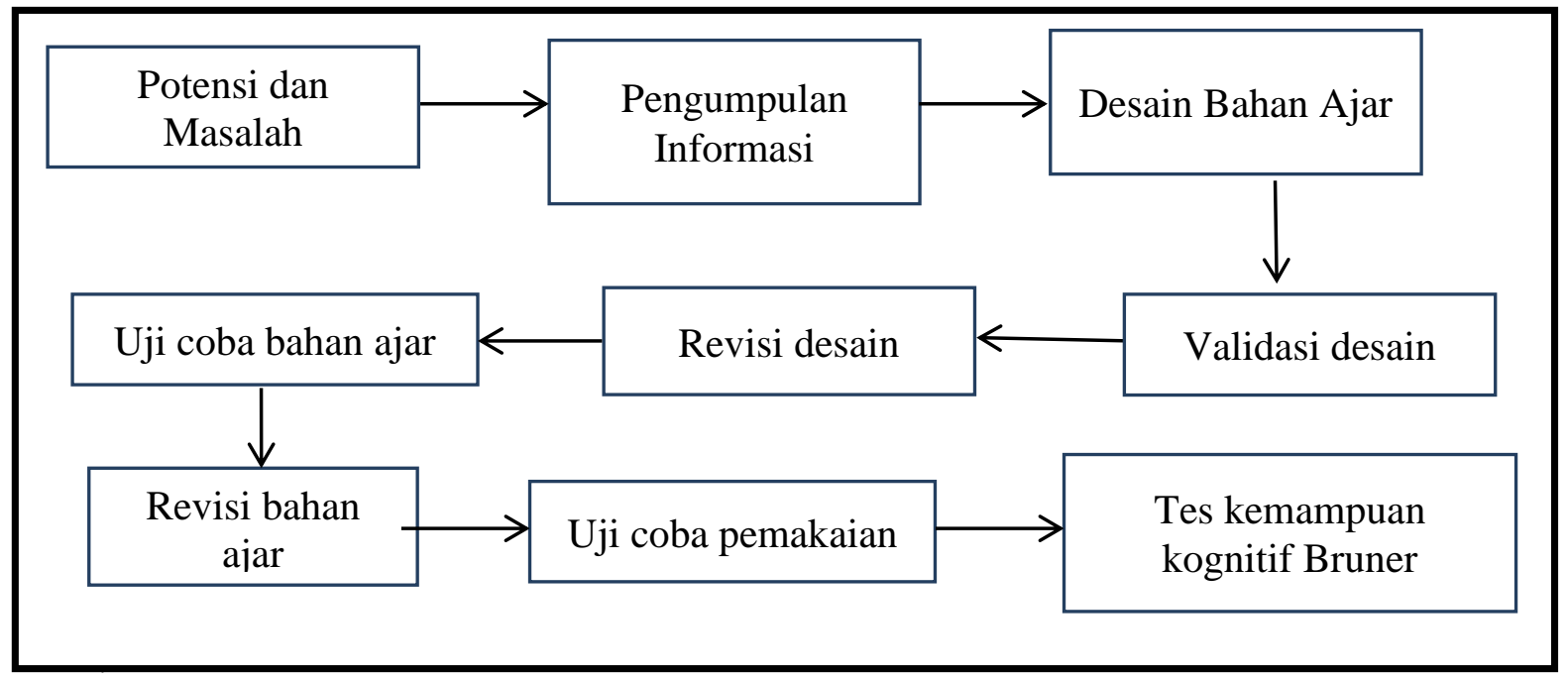

Gambar 1. Alur Pengolahan Data 


\section{Potensi dan Masalah}

Hal pertama yang harus dilakukan sebelum memulai penelitian dan pengembangan yaitu mengidentifikasi masalah yang ada di sekolah yang akan menjadi tempat penelitian.

Dewasa ini dunia pendidikan sedang mengalami perubahan kepemimpinan yang mengakibatkan timbulnya inovasi-inovasi baru dalam kurikulum. Berdasarkan wawancara, di SMPN 4 Palimanan Kurikulum 2013 pernah diterapkan, namun untuk sekarang sudah kembali lagi pada Kurikulum Tingkat Satuan Pendidikan (KTSP). Perubahan ini disertai pergantian bahan ajar yang digunakan peserta didik. Hal tersebut menjadikan minat membaca peserta didik menjadi menurun karena kebingungan buku ajar yang digunakan. Peserta didik bingung dengan adanya pergantian buku ini yang mengakibatkan motivasi belajar peserta didik dalam belajar matematika pun menurun.

Penurunan minat membaca dan motivasi belajar siswa itu dapat dilihat dari nilai ulangan harian peserta didik yang belum mencapai KKM. Oleh karena itu untuk menumbuhkan kembali minat mem-baca dan motivasi belajar siswa perlu adanya inovasi dari bahan ajar yang digunakan. Berdasarkan permasalahan tadi maka peneliti mengembangkan bahan ajar kubus dan balok berbentuk leaflet berbasis kemampuan kognitif siswa berdasarkan teori Bruner.

\section{Pengumpulan Informasi}

Pengumpulan data penelitian dan pengembangan dilakukan untuk mengetahui tahapan-tahapan penelitian yang dijadikan sebagai acuan dalam mengembangkan bahan ajar.Pengumpulan data ini meliputi data peserta didik dan juga data-data materi ajar yang diperlukan.

\section{Desain Bahan Ajar}

Berdasarkan hasil pengumpulan data, selanjutnya peneliti membuat desain bahan ajar kubus dan balok berbentuk leaflet berbasis kemampuan kognitif siswa berdasarkan teori Bruner. Bahan ajar yang dikembangkan di desain seringkas mungkin supaya peserta didik tidak bingung dalam memahami materi. Bahan ajar leaflet ini dilengkapi dengan motivasi-motivasi supaya peserta didik merasa tertarik dalam membaca dan menimbulkan motivasi belajar. Peneliti membuat 3 buah bahan ajar leaflet yang terdiri dari sub materi pengertian kubus dan balok, jaring-jaring kubus dan balok, yang terakhir luas permukaan dan volume kubus dan balok, terdiri dari 3 lipatan dan 2 halaman bolakbalik setiap satu buah leafletnya.

Berikut muatan bahan ajar leaflet yang didesain: 1) Judul sub bab, 2) Tujuan pembelajaran, 3) Materi tahap enaktif, 4) Motivasi belajar, 5) Materi tahap ikonik, 6) Materi tahap simbolik, 7) Contoh soal, 8) Latihan soal

Kegiatan selanjutnya setelah membuat bahan ajar, peneliti kemudian menyusun tes evaluasi siswa setelah menggunakan bahan ajar kubus dan balok berbentuk leaflet berbasis kemampuan kognitif siswa berdasarkan teori Bruner, kegunaan dari tes ini yaitu untuk melihat ketuntasan belajar siswa setelah belajar menggunakan bahan ajar leaflet.

\section{Validasi Desain Bahan Ajar Leaflet}

Validasi desain merupakan proses untuk menilai rancangan produk. Peneliti meminta 3 orang ahli untuk menilai produk yang sedang dikembangkan supaya dapat diketahui kelemahan dan kelebihan dari produk yang dikembangkan. Adapun para ahli yang diminta menjadi validator adalah 
dua orang dosen matematika IAIN Syekh Nurjati Cirebon yaitu Bapak Arif Muchyidin, M.Si. dan Bapak Toheri, M.Pd. serta satu guru matematika SMPN 4 Palimanan yaitu Bapak H. Sukana, S. Pd.

\section{Revisi Desain Bahan Ajar Leaflet}

Desain dari bahan ajar leaflet sudah divalidasi oleh para ahli, langkah berikutnya adalah merevisi bahan ajar leaflet sesuai dengan saran dari para ahli.

\section{Uji coba bahan ajar leaflet}

Setelah dilakukan revisi pada bahan ajar leaflet tahap selanjutnya yaitu melakukan uji coba terbatas yang dilakukan di kelas VIII B, hal ini dilakukan untuk mendapatkan tanggapan dari beberapa siswa tentang bahan ajar leaflet sebelum nantinya diuji cobakan secara langsung di kelas VIIID.

\section{Revisi Bahan Ajar Leaflet}

Peneliti telah mendapatkan beberapa saran dari peserta didik mengenai bahan ajar leaflet, maka ada beberapa bagian dari bahan ajar leaflet diperbaiki.

\section{Uji Coba Pemakaian}

Setelah selesai melakukan beberapa revisi, maka pada tahap ini adalah uji coba yang sebenarnya, bahan ajar yang dikembangkan ini diuji cobakan di kelas VIIID dengan jumlah peserta didik 35 orang. Uji coba ini dilakukan selama 2 pertemuan untuk membahas bahan ajar dan 1 pertemuan untuk smelakukan tes evaluasi setelah penggunaan bahan ajar leaflet.

\section{Tes Kemampuan Kognitif Siswa}

Setelah melakukan uji coba yang sebenarnya di kelas VIIID maka peneliti melakukan evaluasi dari penggunaan bahan ajar leaflet. Evaluasi ini bertujuan untuk mengetahui respons peserta didik terhadap bahan ajar leaflet yang telah dikembangkan, selain untuk mengetahui respons dilakukan juga tes evaluasi bagi peserta didik untuk menilai keefektifan dari bahan ajar yang telah dikembangkan.

Kesimpulan dari penelitian dan pengembangan bahan ajar kubus dan balok berbentuk leaflet berbasis kemampuan kognitif siswa berdasarkan teori Bruner ini yaitu menghasilkan bahan ajar leaflet yang telah layak dijadikan sebagai alternatif bahan ajar dalam pembelajaran matematika. Penarikan kesimpulan diambil berdasarkan hasil validasi dari expert judgment dan dilihat dari nilai evaluasi siswa setelah menggunakan bahan ajar leaflet, selain itu kesimpulan diambil dari lembar respon yang dibagikan kepada siswa setelah melakukan pembelajaran menggunakan bahan ajar leaflet.

\section{Tampilan Leaflet}

Bahan ajar yang digunakan dalam penelitian ini yaitu bahan ajar berbentuk leaflet. Berikut ini tampilan bahan ajar kubus dan balok berbentuk leaflet berbasis kemampuan kognitif siswa berdasarkan teori Bruner: 


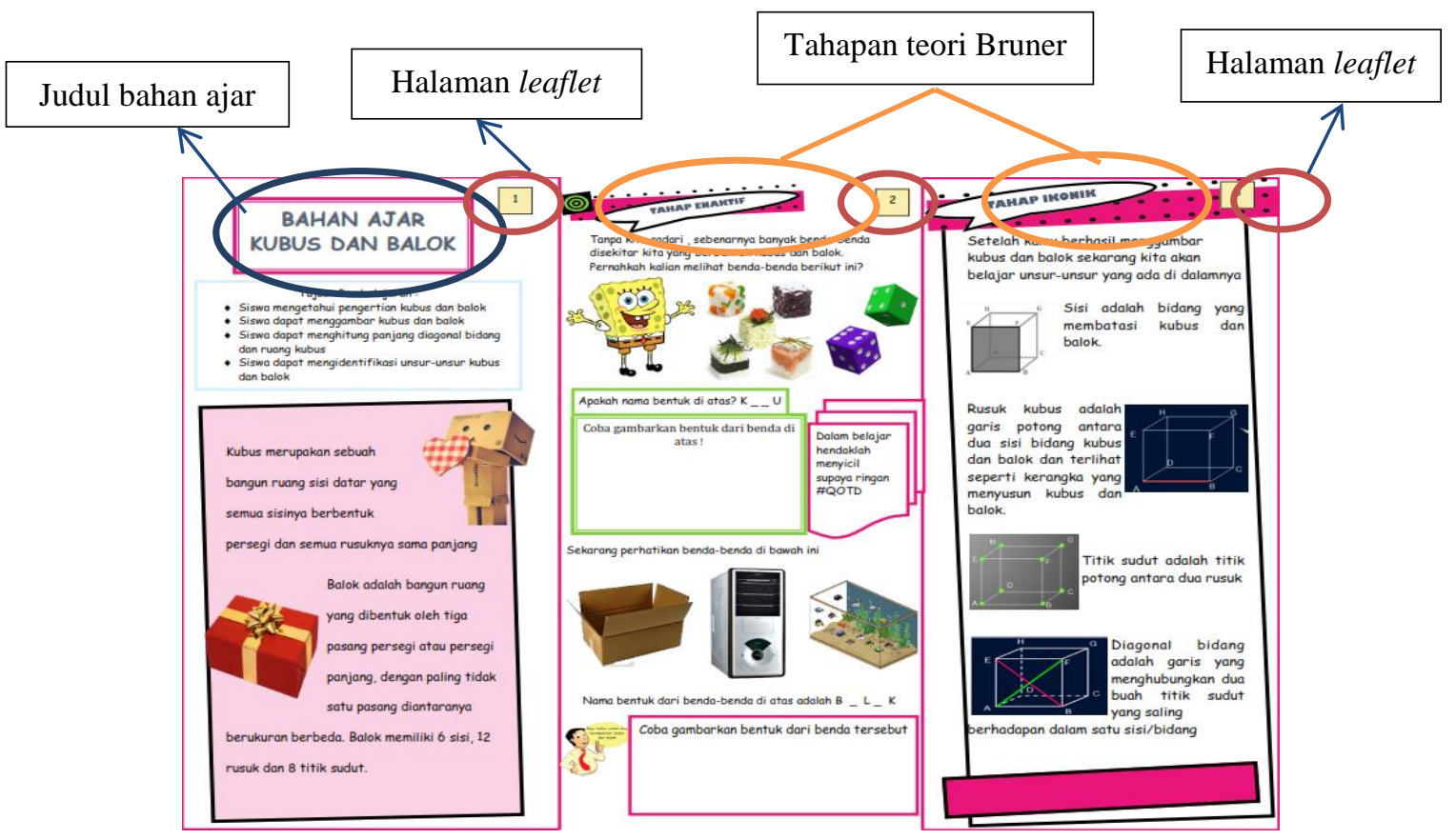

Gambar 2. Tampilan leaflet

\section{Struktur bahan ajar leaflet:}

1. Bahan ajarleaflet terdiri dari tiga lipatan, tiap pojok kanan atas dari tiap lipatan diberi halaman supaya siswa tidak kesulitan mencari halaman selanjutnya yang harus dibaca.

2. Gambar di atas merupakan tampilan depan bahan ajarleaflet yang berisi materi pengertian kubus dan balok.
3. Halaman satu memuat judul bahan ajarnya, di bawah judul bahan ajar berisi tujuan pembelajaran.

4. Susunan materi dalam leaflet ini disusun berdasarkan teori belajar Bruner, yaitu tahap enaktif, ikonik dan simbolik. Pada halaman kedua memuat tahap ikonik, dan pada halaman ketiga memuat tahap ikonik

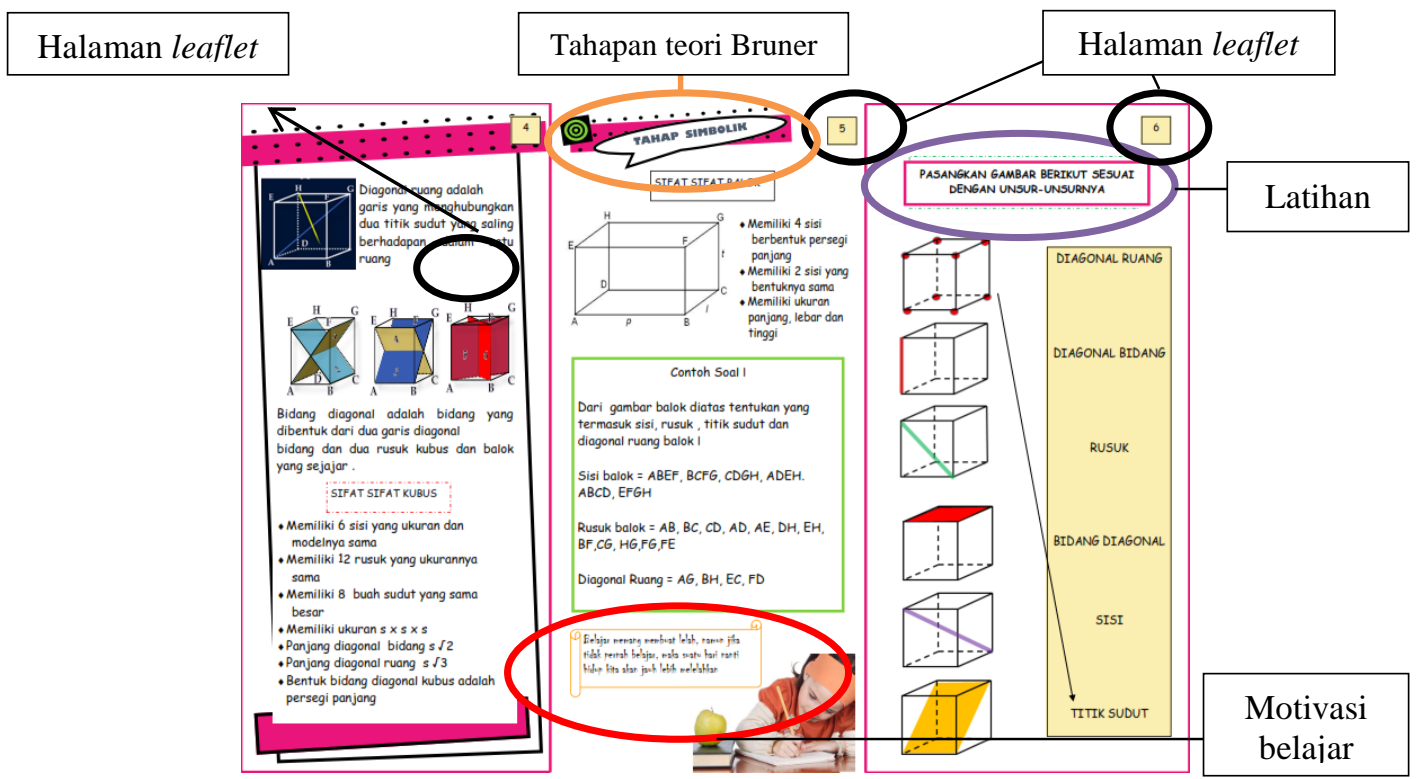

Gambar 3. Bahan Ajar Leaflet 


\section{HASIL DAN PEMBAHASAN}

\section{Deskripsi Hasil Pengambangan Bahan Ajar}

Langkah-langkah yang dilakukan dalam pembuatan bahan ajar kubus dan balok berbentuk leaflet berbasis kemampuan kognitif siswa berdasarkan teori Bruner (1966) ini berpanduan pada langkah-langkah metode penelitian berdasarkan Sugiyono. Langkah-langkahnya adalah sebagi berikut:

\section{Potensi dan Masalah}

Kurangnya inovasi bahan ajar, membuat peneliti ingin mengembangkan bahan ajar kubus dan balok dalam bentuk leaflet, sebelumnya bahan ajar leaflet ini belum pernah diterapkan pada mata pelajaran matematika, namun pada mata pelajaran lain seperti IPA dan IPS pernah ada guru yang menggunakan bahan ajar leaflet.

\section{Pengumpulan Informasi}

Setelah peneliti menelusuri masalah yang ada, peneliti melakukan telaah tentang bahan ajar yang kira-kira dapat menumbuhkan minat membaca siswa dan membangkitkan motivasi belajar siswa. Hal tersebut di pandang penting karena bahan ajar yang menarik dapat meningkatkan motivasi belajar siswa (Amrein \& Berliner, 2003; Wood, 1978).

Peneliti memperhatikan tingkah laku peserta didik ketika pembelajaran matematika berlangsung dan kegiatan peserta didik ketika waktu senggang atau tidak ada guru. Peserta didik terkadang ada yang membawa gitar dan bermain musik ketika istirahat berlangsung. Peserta didik juga sering membuat freehandart atau yang sering dikenal dengan sebutan doodle. Maka dari beberapa kegiatan peserta didik tersebut peneliti menyim- pulkan bahwa peserta didik sering melakukan kegiatan yang berhubungan dengan seni ketika ada waktu luang, yaitu seni mudik dan seni gambar. Oleh karena itu peneliti memilih leaflet sebagai bahan ajar karena leaflet yang dikembangkan berisi gambargambar dan warna-warna yang cerah yang dapat memotivasi siswa untuk membaca.

\section{Desain bahan ajar leaflet}

Langkah selanjutnya setelah menentukan bahan ajar yang akan dikembangkan, maka peneliti membuat desain bahan ajar kubus dan balok berbentuk leaflet berbasis kemampuan kognitif siswa berdasarkan teori Bruner. Kerangka dari leaflet adalah sebagai berikut:

1) Peneliti membuat buah 3 leaflet

2) Setiap laeflet dirancang bolak balik.

3) Setiap halaman kertas dibagi menjadi 3 kolom halaman depan dan 3 kolom halaman belakang.

4) Kolom pertama berisi judul leaflet dan tujuan pembelajaran

5) Kolom kedua, ketiga dan keempat memuat materi

6) Materi disusun berdasarkan tahapan teori Bruner, yaitu adanya tahap enaktif, ikonik dan simbolik.

7) Kolom kelima memuat contoh soal

8) Kolom keenam memuat latihan soal

\section{Validasi desain bahan ajar leaflet}

Setelah bahan ajar selesai di desain atau dirancang, tahap selanjutnya adalah memvalidasi bahan ajar kubus dan balok berbentuk leaflet berbasis kemampuan kognitif siswa berdasarkan teori Bruner melalui 3 expert judgement. 
Tabel 1. Hasil Penilaian Formatif

\begin{tabular}{|c|c|c|c|c|c|}
\hline Aspek & Komponen & $\begin{array}{c}\text { Ahli } \\
1\end{array}$ & $\begin{array}{c}\text { Ahli } \\
2\end{array}$ & $\begin{array}{c}\text { Ahli } \\
3\end{array}$ & $\begin{array}{l}\text { Persentase } \\
\quad(\%)\end{array}$ \\
\hline \multirow{4}{*}{ Kelayakan Isi } & $\begin{array}{l}\text { Kesesuaian materi dengan tujuan } \\
\text { pembelajaran }\end{array}$ & 4 & 4 & 4 & 100 \\
\hline & Kepadatan materi & 2 & 3 & 3 & 66,6 \\
\hline & Pendukung materi pelajaran & 2 & 3 & 3 & 66,6 \\
\hline & Kesesuaian dengan teori Bruner & 3 & 4 & 4 & 91,6 \\
\hline \multirow{3}{*}{ Penggunaan Bahasa } & Kata kata singkat dan lugas & 4 & 4 & 3 & 91,6 \\
\hline & Kalimat efektif & 3 & 4 & 4 & 91,6 \\
\hline & Kejelasan informasi & 3 & 3 & 3 & 75 \\
\hline \multirow{2}{*}{ Tampilan } & Kejelasan gambar & 4 & 4 & 4 & 100 \\
\hline & Huruf menarik & 4 & 3 & 3 & 91,6 \\
\hline \multirow{3}{*}{ Kelengkapan komponen } & Pemberian motivasi & 4 & 3 & 3 & 91,6 \\
\hline & Adanya contoh soal & 3 & 4 & 4 & 91,6 \\
\hline & Adanya latihan & 3 & 4 & 3 & 91,6 \\
\hline Jumlah & & 39 & 43 & 41 & \\
\hline
\end{tabular}

\section{Revisi bahan ajar leaflet}

Setelah peneliti melakukan validasi bahan ajar berbentuk leaflet berbasis kemampuan kognitif siswa berdasarkan teori Bruner, selanjutnya peneliti melakukan perbaikan dari hasil masukan-masukan para ahli sebelum melakukan uji coba terbatas. Berda- sarkan hasil evaluasi yang dilakukan oleh expert judgement terdapat beberapa kritikan dan saran dari para ahli yang harus diperbaiki oleh peneliti. Perbaikan ini dilakukan supaya bahan ajar yang dihasilkan semakin baik dan bisa digunakan sebagai alternatif bahan ajar.

Tabel 2. Komponen yang Perlu Direvisi

- Leaflet belum diberi halaman dan lipatan leaflet masih kurang tepat, urutan membaca leaflet masih kurang jelas sehingga membuat pembaca sulit untuk mengetahui halaman mana yang harus dibaca selanjutnya.

- Melampirkan tujuan pembelajaran

- Tulisan kurang rapi karena masih banyak kata-kata yang terpotong, penulisan rumus harus menggunakan equation tidak boleh di crop.

- Soal latihan kurang banyak

- Tambahkan soal jaring-jaring kubus dan balok yang berhubungan dengan kehidupan sehari-hari

\section{Uji coba bahan ajar leaflet}

Setelah bahan ajar kubus dan balok berbentuk leaflet berbasis kemampuan kognitif siswa berdasarkan teori Bruner direvisi dari hasil saran para ahli, maka peneliti melakukan uji coba terbatas yaitu di kelas VIIIB. Uji coba terbatas adalah uji coba produk atau uji coba bahan ajar berbentuk leaflet untuk mengetahui kekurangan dan kelebihan bahan ajar leaflet dilihat dari pandangan peserta didik. Tahap uji coba ini dilakukan pada 10 siswa yang dipilih secara acak di kelas VIIIB untuk mengetahui respons siswa terhadap bahan ajar kubus dan balok berbentuk leaflet berbasis kemampuan kognitif siswa berdasarkan teori Bruner. 
Tabel 3. Tanggapan/Respons Siswa

1. Menarik penuh dengan warna, banyak gambarnya.

2. Ya saya memahami materinya karena ringkas

3. Bagus,karena ada motivasinya

4. Mbuh, gambar jaring-jaring balok bli jelas (tidak tahu, gambar jaring-jaring balok tidak jelas)

5. Soalnya sesuai dengan tujuan pembelajaran, tapi rada susah

6. Soal latihannya suruh diapain, $n g g k$ ngerti.

Berdasarkan hasil uji coba terbatas bahan ajar kubus dan balok berbentuk leaflet berbasis kemampuan kognitif siswa berdasarkan teori Bruner di atas, maka peneliti memperbaiki kekurangan-kekurangan yang di dapat dari pendapat siswa, agar bahan ajar yang dihasilkan bisa menjadi sebuah produk yang baik dan bisa digunakan sebagai alternatif bahan ajar baru.

\section{Revisi bahan ajar leaflet}

Setelah peneliti melakukan uji coba terbatas terhadap peserta didik kelas VIII B, maka di dapatlah beberapa saran dari peserta didik mengenai bahan ajar yang dikembangkan, oleh karena itu supaya bahan ajar leaflet lebih dimengerti siswa saat diujicobakan kepada siswa pada uji coba yang sesungguhnya maka peneliti merevisi beberapa bagian dari leaflet sesuai dengan saran siswa yaitu mempejelas gamabar jaring-jaring balok, memperjelas petunjuk latihan.

\section{Uji Coba Pemakaian}

Setelah melalui validitas ahli dan uji coba terbatas maka berikutnya produk akan dilakukan uji coba pemakaian. Tahap uji coba pemakaian produk yaitu untuk mengetahui apakah produk bisa dimengerti oleh siswa dan untuk mengetahui kekurangan dan kelemahan produk yang dirancang, sehingga dapat menyempurnakan produk dengan baik juga untuk mengetahui efektivitas dari bahan ajar leaflet yang dikembangkan.

Berdasarkan lembar respons siswa yang disebar di kelas VIIID 80\% dari siswa memberikan tanggapan positif dan sisanya $20 \%$ siswa merasa kurang puas dengan bahan ajar leaflet, sehingga mereka memberikan tanggapan negatif dan saran-saran terhadap bahan ajar yang dikembangkan. Berikut ini beberapa tanggapan positif dan negatif dari siswa.

Tabel 4. Tanggapan Siswa terhadap Pengunaan Bahan Ajar

\begin{tabular}{l}
\hline \multicolumn{1}{c}{ Tanggapan positif } \\
\hline 1. Tampilan leaflet bagus, menarik, tulisannya jelas. \\
2. Jelas dan mudah dipahami \\
3. Adanya tampilan bahan ajar kubus dan balok kita bisa mengerti dan bisa mengetahui bagaimana caranya, \\
sehingga bisa membuat kita menjadi paham \\
\hline \multicolumn{1}{c}{ Tanggapan negatif } \\
\hline 1. Materinya gampang-gampang susah \\
2. Bahasa yang digunakan harusnya bahasa Jawa supaya tidak bosan \\
3. Bacanya ruwed (rumit ketika membacanya) \\
4. Rada-rada angel bu (sedikit sulit bu)
\end{tabular}

\section{Analisis Data}

Selanjutnya setelah bahan ajar di uji cobakan selama 3 pertemuan maka, pada pertemuan terakhir peneliti mengevaluasi siswa dengan menggunakan instrumen tes dan lembar respons siswa. Adapun tes kemam- 
puan kognitif siswa berdasarkan teori Bruner yang diberikan adalah 17 soal pilihan ganda yang berisi soal tentang kubus dan balok.

Menurut Bruner seiring dengan terjadinya pertumbuhan kognitif, para pembelajar harus memulai tiga tahapan pembelajaran yang terdiri dari tahap enaktif (adanya benda konkret), ikonik (menggambarkan benda konkret) serta simbolik (menyatakan dalam simbol matematika) (Hariyanto, 2011).

Berikut ini penjelasan tiga tahapan perkembangan intelektual menurut Bruner meliputi:

Pertama, Seseorang belajar tentang dunia melalui respons atau aksi-aksi terhadap suatu objek. Dalam memahami dunia sekitarnya anak menggunakan keterampilan dan pengetahuan motorik seperti meraba, memegang, mencengkram, menyentuh, menggigit dan sebagainya. Dalam tahap enaktif ini peserta didik belajar memanipulasi objek-objek secara langsung. Anakanak harus diberi kesempatan bermain dengan berbagai bahan/alat pembelajaran tertentu agar dapat memahami bagaimana bahan/alat itu bekerja.Contoh tahap enaktif dalam pembelajaran kubus dan balok yaitu, siswa diberikan benda/benda berbentuk kubus dan balok yang berhubungan dengan dunia nyata, misalnya benda yang berbentuk kubus itu dadu dan ka'bah, sedangkan benda berbentuk balok yaitu lemari, kardus, CPU dan lain-lain. Adapun data hasil penelitiaan pada tahap enaktif adalah sebagai beikut.

Tabel 5. Kemampuan Enaktif Siswa

\begin{tabular}{ccccc}
\hline \multirow{2}{*}{ Dimensi Kognitif Bruner } & \multirow{2}{*}{ Nomor Item } & \multicolumn{2}{c}{ Alternatif Jawaban } & \multirow{2}{*}{ Persentase } \\
& & Benar & Salah & 7 \\
Enaktif & 1 & 28 & 4 & $80,0 \%$ \\
& 9 & 31 & & $88,6 \%$ \\
\hline Rata-rata persentase tahap enaktif & & & & $\mathbf{8 4 , 3 \%}$ \\
\hline
\end{tabular}

Dimensi enaktif diwakili oleh dua butir soal, yaitu butir nomor 1 (satu) dan nomor 9 (sembilan). Berdasarkan tabel diatas pada dimensi enaktif, yaitu kemampuan kognitif siswa dalam menjawab soal yang berhubungan dengan dunia nyata atau kehidupan sehari-hari mendapatkan persentase $80 \%$ untuk soal nomer 1 , dan $88,6 \%$ untuk soal nomor 3 yang artinya hampir seluruh siswa bisa menjawab soal yang berhubungan dengan kehidupan sehari-hari. Dengan demikian persentase rata-rata pada kedua butir soal tersebut adalah $84,3 \%$. Artinya hampir semua siswa bisa mengikuti tahap enaktif dengan baik sehingga mereka dapat menyelesaikan soal yang berhubungan dengan kehidupan sehari-hari.

Hal tersebut sejalan dengan pandangan Lave (1988) pada tahap enaktif, siswa mampu meningkatkan kognitifnya untuk menggunakan atau memanipulasi objek-objek secara langsung pada kegiatan pembelajaran matematika.

Kedua, Pembelajaran terjadi melalui penggunaan model-model, gambar-gambar dan visualisasi verbal. siswa mencoba memahami dunia sekitarnya melalui bentukbentuk perban-dingan (komparasi) dan perumpamaan (tamsil), dan tidak lagi memerlukan manipulasi objek-objek pembelajaran secara langsung. Tahap ikonik ini siswa diharapkan dapat menjelaskan pembelajaran dengan cara menampilkan bentuk sebuah gambar visual di mana siswa mengenal gambar tersebut (Tall, 2004).

Tahap ikonik pada pembelajaran kubus dan balok bisa dicontohkan dengan meng-gambarkan dari benda nyata ke dalam 
bentuk kubus dan baloknya. Misalnya dari bentuk dadu, siswa dapat mengetahui dan menggambarkan bahwa dadu itu berbentuk kubus, sedangkan lemari itu berbentuk balok.

Tabel 6. Kemampuan Ikonik Siswa

\begin{tabular}{|c|c|c|c|c|}
\hline \multirow{2}{*}{ Dimensi Kognitif Bruner } & \multirow{2}{*}{ Nomor Item } & \multicolumn{2}{|c|}{ Alternatif Jawaban } & \multirow{2}{*}{ Persentase } \\
\hline & & Benar & Salah & \\
\hline \multirow{8}{*}{ Ikonik } & 2 & 30 & 5 & $85,7 \%$ \\
\hline & 10 & 26 & 9 & $74,3 \%$ \\
\hline & 6 & 24 & 11 & $68,6 \%$ \\
\hline & 7 & 34 & 1 & $97,1 \%$ \\
\hline & 8 & 29 & 6 & $82,9 \%$ \\
\hline & 4 & 31 & 4 & $88,6 \%$ \\
\hline & 11 & 21 & 14 & $60,0 \%$ \\
\hline & 17 & 29 & 6 & $82,9 \%$ \\
\hline Rata-rata persentase tahap ikonik & & & & $\mathbf{8 0 , 0 \%}$ \\
\hline
\end{tabular}

Dimensi ikonik diwakili oleh 8 (delapan) butir soal, yaitu butir nomor 2 (dua), butir nomor 10 (sepuluh), butir nomor 6 (enam, butir nomor 7 (tujuh), butir nomor 8 (delapan) butir nomor 4 (empat), butir nomor 11 (sebelas) dan butir nomor 17 (tujuh belas) - Berdasarkan tabel diatas pada dimensi ikonik, yaitu kemampuan kognitif siswa dalam menjawab soal yang berhu-bungan gambar mendapatkan persentase $85,7 \%$ untuk soal nomer 2 (dua), 97,1\% untuk nomer 7 (tujuh), 82,9\% untuk nomor 8 (delapan), 88,6\% untuk nomor 4 (empat), $82,9 \%$ untuk nomor 17 (tujuh belas) yang artinya hampir seluruh siswa bisa menjawab 5 soal yang berhubungan dengan gambar. Sedangkan untuk nomor 10 (sepuluh) mendapatkan persentase sebesar 74,3\%, 68,6\% untuk nomor 6 (enam), dan $60,0 \%$ untuk nomor 11 (sebelas). Artinya sebagian besar dari siswa dapat menyelesaikan 3 soal yang berhubungan dengan gambar. Untuk rata- rata persentase dari dimensi tahap ikonik ternyata mendapatkan $80 \%$ yang artinya hampir seluruh siswa menjawab benar pada soal yang berhubungan dengan gambar atau pada dimensi ikonik.

Ketiga, Siswa sudah mampu menggambarkan kapasitas berpikir dalam istilahistilah abstrak. Dalam memahami dunia sekitarnya siswa belajar melalui simbolsimbol bahasa, logika, matematika dan sebagainya (McNeil\& Fyfe, 2012).

Komunikasi dilakukan dengan menggunakan sistem simbol. Huruf dan lambang bilangan merupakan contoh sistem simbol. Fase simbolik merupakan tahap final dalam pembelajaran. Contoh lain dari tahap simbolik yaitu konversi dari rumus-rumus matematika misalnya panjang menjadi 'p' lebar menjadi ' 1 ' dan sebagainya, pada tahap ini siswa sudah mengenal dan memahami simbol-simbol atau rumus-rumus matematika.

Tabel 7. Kemampuan Simbolik Siswa

\begin{tabular}{ccccc}
\hline \multirow{2}{*}{ Dimensi Kognitif Bruner } & \multirow{2}{*}{ nomor item } & \multicolumn{2}{c}{$\begin{array}{c}\text { Alternatif jawaban } \\
\text { Benar }\end{array}$} & $\begin{array}{c}\text { Salah } \\
\text { Persentase }\end{array}$ \\
\hline \multirow{2}{*}{ Simbolik } & 3 & 33 & 2 & $94,3 \%$ \\
& 15 & 33 & 2 & $94,3 \%$ \\
& 5 & 25 & 10 & $71,4 \%$ \\
& 12 & 27 & 8 & $77,1 \%$ \\
& 14 & 24 & 11 & $68,6 \%$ \\
& 13 & 25 & 10 & $71,4 \%$ \\
\hline
\end{tabular}


JIPM (Jurnal Ilmiah Pendidikan Matematika), 6(1), September 2017- 22

Widodo Winarso, Dede Dewi Yuliyanti

\begin{tabular}{ccccc}
\hline \multirow{2}{*}{ Dimensi Kognitif Bruner } & \multirow{2}{*}{ nomor item } & \multicolumn{2}{c}{$\begin{array}{c}\text { Alternatif jawaban } \\
\text { Benar }\end{array}$} & \begin{tabular}{c} 
Palah \\
\cline { 2 - 5 }
\end{tabular} \\
\cline { 2 - 5 } & 16 & 31 & 4 & Persentase \\
\hline Rata-rata persentase tahap simbolik & & & & $\mathbf{8 0 , 8 \%}$ \\
\hline
\end{tabular}

Dimensi simbolik diwakili oleh 7 (tujuh) butir soal, yaitu butir nomor 3 (tiga), butir nomor 15 (lima belas), butir nomor 5 (lima), butir nomor 12 (dua belas), butir nomor 14 (empat belas), butir nomor 13 (tiga belas) dan butir nomor 16 (enam belas). Berdasarkan tabel diatas pada dimensi simbolik, yaitu kemampuan kognitif siswa dalam menjawab soal yang berhubungan rumus-rumus atau simbol matematika mendapatkan persentase $94,3 \%$ untuk soal nomer 3 (tiga), 94,3\% untuk nomer 15 (lima belas), $88,6 \%$ untuk nomor 16 (enam belas), yang artinya hampir seluruh siswa bisa menjawab 3 soal yang berhubungan dengan rumus matematika. Sedangkan untuk nomor 5 (lima) mendapatkan persentase sebesar 71,4\%, $77,1 \%$ untuk nomor 12 (dua belas), dan 68,6\% untuk nomor 14 (empat belas), 71,4\% untuk soal nomor 13 (tiga belas). Artinya sebagian besar dari siswa dapat menyelesaikan 4 soal yang berhu-bungan dengan rumus matematika. Untuk rata-rata persentase dari dimensi tahap simbolik ternyata mendapatkan $80,8 \%$ yang artinya hampir seluruh siswa menjawab benar pada soal yang berhubungan dengan simbol atau angka matematika atau pada kemampuan simbolik.

Peserta didik SMPN 4 Palimanan telah menyelesaikan soal kognitif siswa berdasarkan teori Bruner, yaitu berhasil menjawab soal yang yang berhubungan dengan bentuk enaktif sebesar $84,3 \%$, soal bentuk ikonik sebesar $80,0 \%$, soal bentuk simbolik sebesar $80,8 \%$. Berikut ini rekapitulasi kemampuan kognitif siswa berdasarkan teori Bruner pada matri kubus dan balok pada diagram lingkaran.

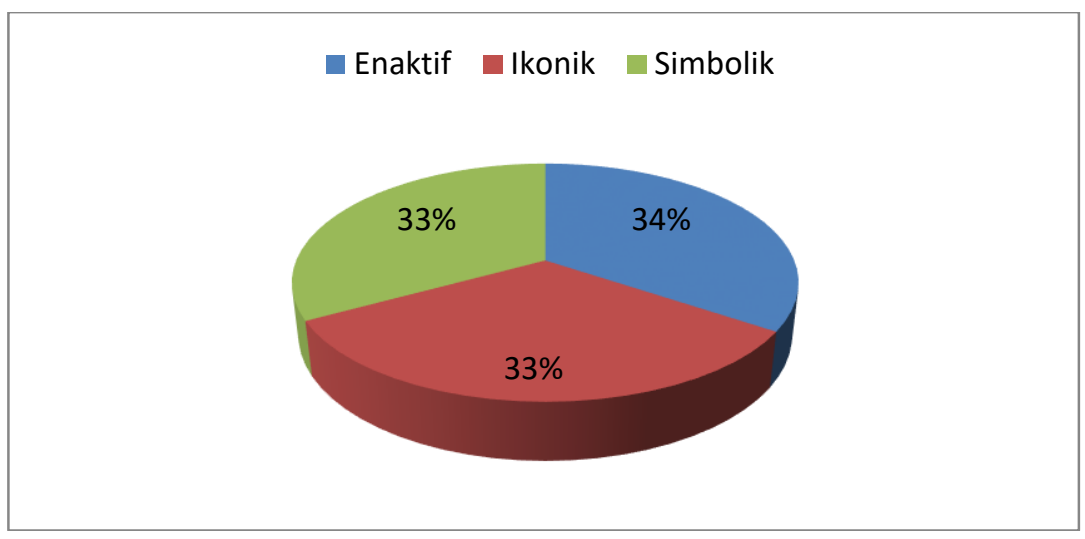

Gambar 4. Proporsi Kemampuan Kognitif Berdasarkan Teori Bruner

Berdasarkan bagan di atas diketahui bahwa keseluruhan tes 17 butir soal pilihan ganda yang dilakukan untuk mengukur kemampuan kognitif siswa berdasarkan teori Bruner. Peserta didik dapat menyelesaikan soal-soal kognitif Bruner yaitu soal yang berhubungan dengan kehidupan sehari-hari (enaktif) sebesar 34\%, soal yang berhubungan dengan gambar (ikonik) sebesar 33\%, soal yang berhubungan dengan simbol matematika (sim-bolik) sebesar 33\%. Dari persentase tersebut diketahui bahwa peserta 
didik memperoleh persentase tertinggi pada soal enaktif yaitu sebesar $34 \%$, sedangkan untuk persentase soal ikonik dan simbolik sebesar 33\%. Dengan demikian bahwa peserta didik lebih dapat menjawab soal yang berhubungan dengan kehidupan sehari-hari dari pada soal yang berhubungan dengan gambar dan simbol-simbol matema-tika.

Berdasarkan lembar respons siswa bahan ajar leaflet mendapat sambutan positif dari peserta didik karena belum pernah ada sebelumnya. Maka dapat ditarik kesimpulan bahwa bahan ajar kubus dan balok berbentuk leaflet berbasis kemampuan kognitif siswa berdasarkan teori Bruner layak dijadikan sebagai alternatif bahan ajar yang bisa digunakan dalam pembelajaran kubus dan balok.

\section{SIMPULAN}

Berdasarkan hasil pembahasan didapat bahwa masalah yang ada di lingkungan sekolah SMPN 4 Palimanan diantaranya ditemukan bahwa optimalnya penggunaan bahan ajar dan minat membaca siswa. Sedangkan untuk potensi siswanya mereka menyukai doodle art oleh karena itu di pilihlah leaflet sebagai bahan ajar yang dikembangkan.

Bahan ajar leaflet dirancang bolak balik, dalam satu kertas terdapat tampilan depan dan tampilan belakang. Kertas yang digunakan adalah A4 yang dibagi menjadi 3 kolom. Susunan dari bahan ajar leaflet yaitu: (1) kolom pertama berisi judul leaflet dan tujuan pembelajaran (2) kolom kedua, ketiga dan keempat memuat materi yang disusun berdasarkan teori Bruner yaitu terdapat tahap enaktif, ikonik dan simbolik. (3) kolom kelima memuat contoh soal, (4) kolom keenam berisi latihan soal. Proses pengembangan leaflet dimulai dari validasi bahan ajar oleh ahli, setelah itu revisi. Beberapa masukan dari ahli diantaranya, leaflet harus ada halaman, latihan soal harus diperbanyak, simbol matematika harus menggunakan equation. Setelah revisi kemudian dilakukan uji coba terbatas, lembar respons siswa uji coba terbatas diantaranya, leaflet bagus dan menarik, tapi gambar jaring-jaring balok dan petunjuk latihan masih kurang jelas. Peneliti melakukan revisi ber-dasarkan saran dari siswa. Setelah revisi selesai maka bahan ajar leaflet diuji cobakan pada kelas yang sesungguhnya.

Berdasarkan lembar respons siswa yang disebar, $80 \%$ dari siswa memberikan tanggapan positif terhadap bahan ajar kubus dan balok berbentuk leaflet berbasis kemampuan kognitif siswa berdasarkan teori Bruner. Peserta didik dapat menyelesaikan soal-soal kognitif Bruner yaitu soal yang berhubungan dengan kehidupan sehari-hari (enaktif) sebesar $34 \%$, soal yang berhubungan dengan gambar (ikonik) sebesar $33 \%$, soal yang berhubungan dengan simbol matematika (simbolik) sebesar 33\%. peserta didik lebih bisa menjawab soal yang berhubungan dengan kehidupan sehari-hari dari pada soal yang berhubungan dengan gambar dan simbol-simbol matematika. Oleh karena itu, peneliti menyimpulkan bahwa bahan ajar kubus dan balok berbentuk leaflet dinyatakan efektif dan layak digunakan dalam pembelajaran matematika 


\section{DAFTAR PUSTAKA}

Amrein, A. L., \& Berliner, D. (2003). Student Motivation and Learning. NJ USA: $H W$ Wilson Co.

Arikunto, S. (2010). Suatu pendekatan praktek. Cetakan ke-14. Jakarta.

Baswedan, A. R. (2014, December). Gawat darurat pendidikan di Indonesia. In The Emergency of Indonesian Education]. A paper delivered at the meeting between Ministry and Head of Education Offices Indonesia-wide in Jakarta, on December (Vol. 1).

Bruner, J. S. (1966). Toward a theory of instruction (Vol. 59). Harvard University Press.

Calinger, R., Brown, J. E., \& West, T. R. (1999). A contextual history of mathematics: To Euler. Upper Saddle River, NJ: Prentice Hall.

Chatib, M. (2012). Orangtuanya manusia: melejitkan potensi dan kecerdasan dengan menghargai fitrah setiap anak. Kaifa.

Fajar, M. (1993). Administrasi dan Supervisi Pendidikan. Yogyakarta: Aditya Media.

Gallenstein, N. L. (2003). Creative Construction of Mathematics and Science Concepts in Early Childhood. Association for Childhood Education International, 17904 Georgia Avenue, Suite 215, Olney, MD 20832.

Hariyanto, S. (2011). Belajar dan Pembelajaran: Teori dan Konsep Dasar. Bandung: Penerbit PT Remaja Rosdakarya.

Kothari, C. R. (2004). Research methodology: Methods and techniques. New Age International.

Krismanto, A. (2003). Beberapa teknik, model, dan strategi dalam pembelajaran matematika. Yogyakarta: Depdiknas Dirjen Pendidikan Dasar dan Menengah.

Lave, J. (1988). Cognition in practice: Mind, mathematics and culture in everyday life. Cambridge University Press.

Lestari, D. (2014). Penerapan Teori Bruner Untuk Meningkatkan Hasil Belajar Siswa Pada Pembelajaran Simetri Lipat di Kelas IV SDN 02 Makmur Jaya Kabupaten Mamuju Utara. Jurnal Kreatif Tadulako Online, 3(2). 129-141
McNeil, N. M., \& Fyfe, E. R. (2012). "Concreteness fading" promotes transfer of mathematical knowledge. Learning and Instruction, 22(6), 440-448.

Olson, D. R. (2014). Jerome Bruner: The cognitive revolution in educational theory. Bloomsbury Publishing.

Otieno, K. O. (2010). Teaching/learning resources and academic performance in mathematics in secondary schools in Bondo District of Kenya. Asian Social Science, 6(12), 126.

Purnomo, D. (2012). Pengembangan Bahan Ajar Matematika Sebagai Sarana Pengembangan Kreativitas Berpikir. AKSIOMA, 2(1/Maret).

Putra, A. K. (2015). Resistensi Finlandia terhadap Global Educational Reform Movement (Doctoral dissertation, Universitas Airlangga).

Septiani, E. T., Jalmo, T., \& Yolida, B. (2014). Penggunaan bahan ajar leaflet terhadap hasil belajar siswa. Jurnal Bioterdidik, 2(4).

Stodolsky, S. S., Salk, S., \& Glaessner, B. (1991). Student views about learning math and social studies. American educational research journal, 28(1), 89-116.

Sugiyono. (2008). kualitatif dan R\&D. Bandung: Alfabeta

Suriasumantri, J. S. (1999). Ilmu dalam perspektif. Yayasan Obor Indonesia.

Tall, D. (2004). Thinking through three worlds of mathematics. In Proceedings of the 28th Conference of the International Group for the Psychology of Mathematics Education (Vol. 4, pp. 281-288).

Van den Akker, J. (1999). Principles and methods of development research. In Design approaches and tools in education and training (pp. 1-14). Springer Netherlands.

Wood, K. E. (1978). What motivates students to teach?. Journal of Teacher Education, 29(6), 48-50.

Yunanto, S. J. (2004). Sumber Belajar Anak Cerdas. Jakarta : Grasindo. 